\title{
Coats disease with exudative retinal detachment simulating cysticercus cyst: misleading ultrasonography!
}

\author{
Vineet Mutha, Sahil Agrawal, Parijat Chandra, Atul Kumar
}

Dr Rajendra Prasad Centre for Ophthalmic Sciences, All India Institute of Medical Sciences, New Delhi, India

\section{Correspondence to Dr Vineet Mutha,} neetvinit@gmail.com

Accepted 11 November 2017

\section{DESCRIPTION}

A 5 -year-old boy was brought to our clinic when parents noticed white reflex and divergent squint in the left eye. Snellen visual acuity was 20/20 in the right eye and inaccurate projection of rays in the left eye along with a 30 prism dioptre divergent squint in the latter. Anterior segment was within normal limits in both eyes on slit lamp evaluation. As the child was uncooperative for detailed fundus examination, we performed an ocular ultrasonography. Ocular ultrasonography of the left eye showed an intraocular cystic mass with a localised hyperechoic area adjacent to cyst wall which is typical of a cysticercus cyst with scolex (figure 1). On Optomap ultra-wide-field fundus photography (Optos, Scotland, UK) we found that the cystic mass on ultrasonography was actually a localised exudative retinal detachment and the scolex-like area of hyperechogenicity was a large confluent exudate collection in the subretinal space within the retinal detachment. Ultrawide-field fluorescein angiography on Optos of the left eye additionally showed telangiectatic and aneurysmal vessels and multiple areas of peripheral capillary non-perfusion which led to a definitive diagnosis of Coats disease (figure 2).

Ultrasonography has long been known to be an essential tool for diagnosing ocular and orbital cysticercosis. Its diagnostic accuracy is $>80 \%$ and has been shown to be more informative than CT in diagnosing ocular cysticercosis. ${ }^{1}$ Visual acuity is worse than Snellen 20/200 in about 60\%-80\% cases of intraocular cysticercosis though a very low visual acuity in order to cause an afferent

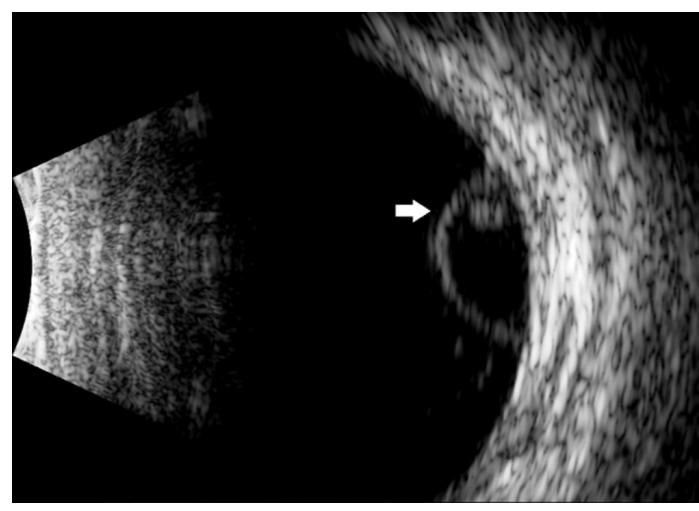

Chandra $\mathrm{P}$, et al. BMJ Case Rep Published Online First: [please include Day Month Year]. doi:10.1136/bcr-2017222975

CrossMark
Figure 1 Ocular ultrasonography B scan showing an intraocular cystic mass with localised hyperechoic area (white arrow).

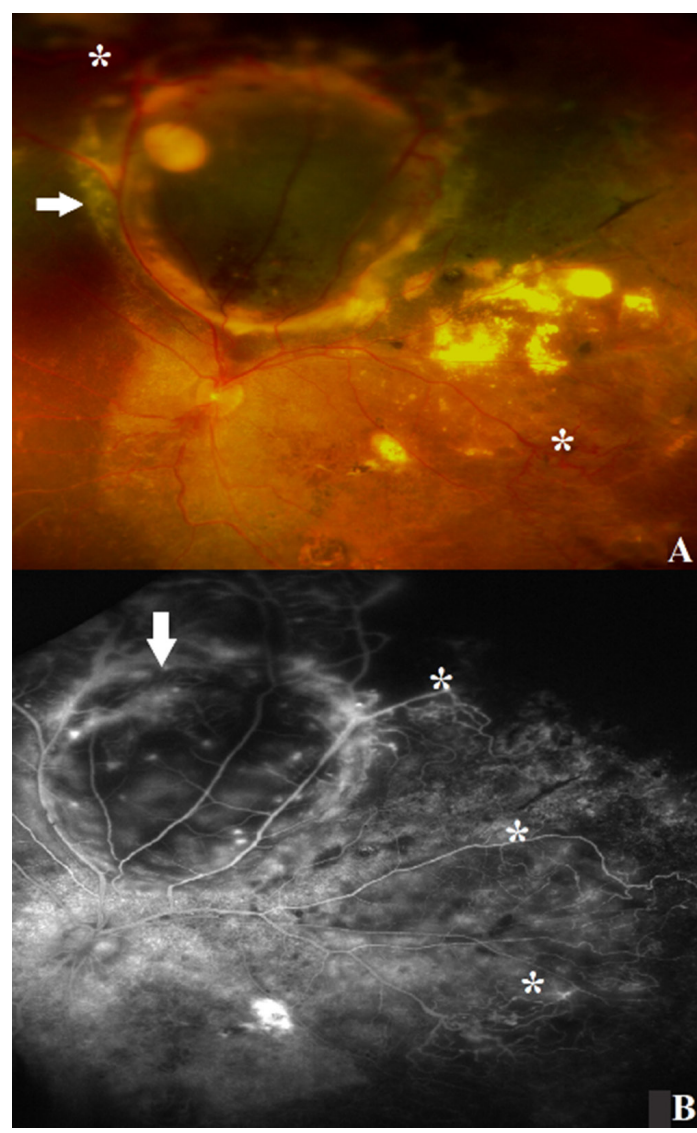

Figure 2 Optos ultra-wide-field fundus photography (A) showing exudative retinal detachment (white arrow) and multiple areas of vascular telangiectasia and aneurysms (white asterisk); fluorescein angiography (B) showing peripheral areas of capillary non-perfusion (white asterisk) along with vascular telangiectasia and exudative detachment with vascular aneurysms (white arrow).

pupillary defect is uncommon. ${ }^{2}$ Most common clinical signs in cases of intraocular cysticercosis are vitritis and undulating movements of the cyst on ultrasonography which were absent in current case scenario despite typical appearance of cyst with adherent scolex to the cyst wall like a 'hanging drop' on ultrasonography. ${ }^{2-4}$ Inaccurate projection of rays and leukocoria in the affected eye in our case caused a diagnostic dilemma as these are not usually associated with cysticercosis.

Optomap ultra-wide-field imaging is a valuable modality for visualising fundus in children and uncooperative patients. It proved to be an important diagnostic tool in the current case as it 


\section{Learning points}

- Ultrasonography is highly sensitive for diagnosing ocular cysticercosis but its specificity should be questioned.

- Optomap ultra-wide-field photography is a valuable tool for detailed fundus assessment in uncooperative patients.

- Cysticercosis and Coats disease fall within the spectrum of differential diagnosis of each other.

refuted ultrasonography findings which are considered highly sensitive for diagnosing intraocular cysticercosis.

Coats disease is a unilateral disorder which affects boys aged 5-10 years. Characteristically it leads to vascular telangiectasia with exudation and aneurysms. ${ }^{5}$ Leukocoria, squint and low visual acuity are the most common presenting features. ${ }^{5}$ All these features were present in our case, confirming the diagnosis of Coats disease, while ultrasonography proved to be falsely positive for cysticercosis.
Contributors VM: case selection and manuscript preparation. SA: image retrieval. PC: manuscript and image editing. AK: image capture and guidance.

Competing interests None declared.

Patient consent Obtained.

Provenance and peer review Not commissioned; externally peer reviewed.

(c) BMJ Publishing Group Ltd (unless otherwise stated in the text of the article) 2018. All rights reserved. No commercial use is permitted unless otherwise expressly granted.

\section{REFERENCES}

1 Rath S, Honavar SG, Naik M, et al. Orbital cysticercosis: clinical manifestations, diagnosis, management, and outcome. Ophthalmology 2010;117:600-5.

2 Wender JD, Rathinam SR, Shaw RE, et al. Intraocular cysticercosis: case series and comprehensive review of the literature. Ocul Immunol Inflamm 2011;19:240-5.

3 Dhiman R, Devi S, Duraipandi K, et al. Cysticercosis of the eye. Int J Ophthalmol 2017;10:1319-24

4 Gulani AC. Sonographic diagnosis of orbital cysticercus cyst: the "Hanging Drop Sign". Journal of Diagnostic Medical Sonography 1998;14:122-4.

5 Sigler EJ, Randolph JC, Calzada JI, et al. Current management of Coats disease. Surv Ophthalmol 2014;59:30-46.

Copyright 2017 BMJ Publishing Group. All rights reserved. For permission to reuse any of this content visit

http://group.bmj.com/group/rights-licensing/permissions.

BMJ Case Report Fellows may re-use this article for personal use and teaching without any further permission.

Become a Fellow of BMJ Case Reports today and you can:

- Submit as many cases as you like

- Enjoy fast sympathetic peer review and rapid publication of accepted articles

- Access all the published articles

Re-use any of the published material for personal use and teaching without further permission

For information on Institutional Fellowships contact consortiasales@bmjgroup.com

Visit casereports.bmj.com for more articles like this and to become a Fellow 